\title{
AGGREGATE STABILITY IN SOILS OF TWELVE AGRO-ECOLOGICAL ZONES OF BANGLADESH BASED ON ORGANIC CARBON AND BASIC CATIONS
}

\author{
S. Arofi ${ }^{1}$, M. M. Rahman ${ }^{1 *}$, H. K. Shiragi ${ }^{2}$, M. A. Alam ${ }^{1}$, M. M. Islam ${ }^{3}$, and J. C. Biswas ${ }^{4}$
}

\begin{abstract}
Soil aggregate is one of the vital indicators of soil health that depends on organic carbon (OC), texture and basic cations. A total of 206 soil samples were collected from 12 agroecological zones (AEZs) of Bangladesh to study the effects of organic carbon (OC), basic cations $(\mathrm{Ca}, \mathrm{Mg}, \mathrm{K}$ and $\mathrm{Na}$ ) and different sized soil particles on soil aggregate stability. Soil samples were analyzed for bulk density, $\mathrm{pH}, \mathrm{OC}$, texture, basic cations and water stable soil aggregates (WSA) following standard protocols. Data revealed that OC positively increased WSA, while monovalent basic cations $\mathrm{Na}^{+}$and $\mathrm{K}^{+}$showed negative effects. Water stable soil aggregates and $\mathrm{C}$ stock of $0.25 \mathrm{~mm}$ sized soil fraction were found higher than that of larger sized soil fractions of $0.5,1.0$ and $2.0 \mathrm{~mm}$. The roles of divalent basic cations $\mathrm{Ca}^{2+}$ and $\mathrm{Mg}^{2+}$ on WSA were found to be indistinct and need to be studied further.
\end{abstract}

Keywords: Soil aggregates, carbon stock, soil fraction, soil health.

\section{Introduction}

Soil carbon $(\mathrm{C})$ contents and aggregates are very important for sustaining soil health and crop productivity. Conservation and retention of terrestrial $\mathrm{C}$ in soil are very important in mitigating negative effects of global warming and climate change as well as in improving soil quality. Soil aggregation is a continuous process where organic matter plays a dominant role which depends on organic matter supply through addition of crop residues during harvest, application of different manures and composts, biochar, basic cations in soils, microbial abundance and soil and crop management practices. Soil aggregate is a basic factor influencing the functions of soils which has the ability to support plant and animal life. Aggregate stability is used as an indicator of soil structure (Six et al., 2000). Aggregation in soil results from the rearrangement of particles, flocculation and cementation (Duiker et al., 2003). Aggregate stability is important for enhancing porosity, improving drainage, improving soil fertility, increasing agronomic productivity and decreasing erosion.

Aggregation is mediated by biota, ionic bridging, clay, soil organic carbon (SOC) and carbonates. SOC acts as a binding agent and as a nucleus in the formation of aggregates. Depletion of SOC through continuous deep tillage and intensive cropping are major

\footnotetext{
${ }^{1}$ Department of Soil Science, Bangabandhu Sheikh Mujibur Rahman Agricultural University, Gazipur 1706, ${ }^{2}$ Soil Resource Development Institute, Dhaka 1215, ${ }^{3}$ Department of Agronomy, Bangabandhu Sheikh Mujibur Rahman Agricultural University, Gazipur 1706, ${ }^{4}$ Krishi Gobeshona Foundation, Dhaka 1215, Bangladesh.

*Corresponding author:mizan@bsmrau.edu.bd
} 
causes of reduction of stable soil aggregates (Six et al., 2002; Rahman, 2013). If soil disturbance through tillage reduces, the rate of SOC mineralization decreases and consequently SOC storage increases (Paustian et al., 1997; Putte et al., 2010; Schimel and Schaeffer, 2012). SOC storage in agricultural soils has the greatest potential to improve soil aggregates as well as soil health. Since the clay particles and organic matter act as glues to create aggregates, soils having high organic matter and clay can accumulate more $\mathrm{C}$ through sequestration and exhibit stronger soil aggregation. The $\mathrm{OC}$ content in soils of Bangladesh is low because of faster microbial decomposition of soil organic matter (SOM) mediated by high temperature and moisture and also as a consequence of application of little or no organic fertilizer to soils (BARC, 2018; Rahman, 2013). Moreover, crop production in Bangladesh solely depends on inorganic fertilizers where nitrogenous fertilizers especially urea alone contributes $55 \%$ of the total inorganic fertilizers, which also results in faster microbial decomposition of SOM (Alam et al., 2019). Soil aggregate stability in the coastal saline zone is low since monovalent cations sodium $\left(\mathrm{Na}^{+}\right)$and potassium $\left(\mathrm{K}^{+}\right)$have dispersive effects, while in the calcareous region soil aggregates stability is high due to divalent cations calcium $\left(\mathrm{Ca}^{2+}\right)$ and magnesium $\left(\mathrm{Mg}^{2+}\right)$ which have flocculation effects in soils (Rengasamy and Marchuk, 2011). Moreover, the coastal saline soils are high in divalent cation $\mathrm{Mg}^{2+}$, which acts as a monovalent cation and has dispersing effect. In a study Roy et al. (2019) found that soil C positively related to the formation of soil aggregates. However, in general, studies on soil aggregates and factors affecting soil aggregate formation in Bangladesh are rather scanty. Therefore, the present study was conducted to evaluate the effects of organic $\mathrm{C}$, basic cations and different sized soil particles on the stability of soil aggregates in different agro-ecological zones (AEZs) of Bangladesh.

\section{Materials and Methods}

\section{Study sites and soil sample collection}

The study was conducted using soil samples collected from 12 agro-ecological zones (AEZs) of Bangladesh viz., Old Himalayan Piedmont Plain (AEZ 1), Tista Meander Floodplain (AEZ 3), KaratoyaBangali Floodplain (AEZ 4), Ganges Tidal Floodplain (AEZ 13), Old Meghna Estuarine Floodplain (AEZ 19), Northern and Eastern Piedmont Plain (AEZ 22), Chittagong Coastal Plain (AEZ 23), Level Barind Tract (AEZ 25), North-eastern Barind Tract (AEZ 27), Madhupur Tract (AEZ 28), Northern and Eastern Hills (AEZ 29) and Akhaura Terrace (AEZ 30). The numbers of collected soil samples of the mentioned AEZs were $10,10,12,20,7,14,15,12,10,73,16$ and 7 , respectively with a total of 206 soil samples. Soil samples $(0-15 \mathrm{~cm})$ were collected from arable land during November to December in both 2017 and 2018 after harvesting of transplanted aman rice using core samplers to determine soil bulk density. A bulk sample from each sampling point was also collected to analyze other soil parameters. The soil samples were air dried, ground and sieved $(2 \mathrm{~mm})$ and analyzed in the Laboratory of Soil Science Department, BSMRAU, Gazipur. 


\section{Soil sample analysis}

The soil samples were analyzed for bulk density, texture, $\mathrm{pH}$, organic $\mathrm{C}, \mathrm{Na}, \mathrm{K}, \mathrm{Ca}$, $\mathrm{Mg}$ and water stable soil aggregates. For aggregates, soil was sieved by four different sized sieves $(2,1,0.5$ and $0.25 \mathrm{~mm})$ and water stable soil aggregates were determined by the wet sieving method. To determine aggregates, $10 \mathrm{~g}$ air dried soil sample was taken in $50 \mathrm{ml}$ conical flask and the sample was kept overnight under water. The soaked soil samples were then transferred to sieves of respective sizes. Sieves with soil were taken to agitation rack placed under water in plastic box containing $15 \mathrm{~L}$ water and agitated 20 times per 40 seconds. Then sieves were kept in oven at $105^{\circ} \mathrm{C}$ for 2 hours. After complete drying, weight of sieves with soil was recorded and again agitated in $\mathrm{NaOH}$ solution $(1.6 \mathrm{~g} / \mathrm{L})$. Again sieves were dried in oven and weight of dried sample with sieve was recorded as mentioned above. Empty sieve weight was also recorded and calculation was done following (Castellanos-Navarrete et al., 2013). Soil texture was determined by the Bouyoucos hydrometer method as described by Gee and Baunder (1986). The collected core samples were oven dried at $105^{\circ} \mathrm{C}$ for 24 hours and bulk density was calculated (Rowell, 1994). Soil pH was measured by a glass electrode $\mathrm{pH}$ meter (Horiba model No. M-8L) using a soil: water ratio of 1:2.5 (Jackson, 1973). The basic cations ( $\mathrm{Na}, \mathrm{K}, \mathrm{Ca}$, and $\mathrm{Mg}$ ) were determined by the ammonium acetate extraction method (Thomas, 1982) using an atomic absorption spectrophotometer and reading was taken at a $285.2 \mathrm{~nm}$ wavelength. Organic C was determined by the wet oxidation method (Walkley and Black, 1934). Sodium adsorption ratio (SAR), monovalent cation adsorption ratio (MCAR) and cations ratio of soil structural stability (CROSS) were determined using procedures proposed by Rengasamy and Marchuk (2011). Soil C stock was calculated using the following equation (Rahman et al., 2016).

Soil C stock $\left(\mathrm{t} \mathrm{ha}^{-1}\right)=$ Soil C $\% \times$ soil bulk density $(\mathrm{g} / \mathrm{cc}) \times$ depth of soil $(\mathrm{cm})$

\section{Statistical data analysis}

The data collected on different parameters were subjected to statistical analysis (Gomez and Gomez, 1984). The Microsoft Excel and SPSS 20 software programs were used wherever appropriate to perform statistical analysis. Relationships among the parameters were established through correlation and regression analysis. Mean differences among the treatments were interpreted by using the least significant difference (LSD) test at 5\% level of significance.

\section{Results and Discussion}

\section{Soil physical properties in different AEZs}

Bulk density (BD), texture and aggregate stability of soils of different AEZs are presented in Table 1. Soil BD insignificantly differed among different AEZs ( $p>0.05$ ). The highest BD $(1.45 \mathrm{~g} / \mathrm{cc})$ was recorded in soils of AEZ 27 and 29 , while the lowest density $(1.36 \mathrm{~g} / \mathrm{cc})$ was recorded in soils of AEZ 13. The data on soil BD of the 12 AEZs were found moderate $(1.36-1.45 \mathrm{~g} / \mathrm{cc})$ which revealed that the soils are neither clayey nor sandy. Sand particle $(2.00-0.05 \mathrm{~mm})$ in the soil samples varied from 13.50 to $38.43 \%$, where the highest sand content $(38.43 \%)$ was recorded for soils of AEZ 29 and the lowest (13.50\%) for soils of 
Table 1. Physical characteristics of soil samples collected from different AEZs of Bangladesh

\begin{tabular}{lccccc}
\hline \multirow{2}{*}{ AEZ No. } & \multicolumn{5}{c}{ Soil physical properties (Mean \pm S.E.) } \\
\cline { 2 - 5 } & BD $(\mathrm{g} / \mathrm{cc})$ & Sand (\%) & Silt (\%) & Clay (\%) & TSA (\%) \\
\hline 1 & $1.41 \pm 0.00$ & $33.50 \pm 3.92$ & $40.00 \pm 4.83$ & $26.50 \pm 2.17$ & $42.54 \pm 6.31$ \\
3 & $1.42 \pm 0.01$ & $29.16 \pm 2.99$ & $44.66 \pm 4.67$ & $26.33 \pm 6.04$ & $41.47 \pm 4.26$ \\
4 & $1.39 \pm 0.01$ & $13.50 \pm 3.50$ & $59.50 \pm 2.50$ & $27.00 \pm 1.00$ & $38.44 \pm 2.36$ \\
13 & $1.36 \pm 0.01$ & $26.50 \pm 2.33$ & $36.40 \pm 2.87$ & $37.09 \pm 4.10$ & $26.48 \pm 1.57$ \\
19 & $1.39 \pm 0.02$ & $20.57 \pm 1.87$ & $54.42 \pm 1.52$ & $25.00 \pm 1.43$ & $43.85 \pm 2.88$ \\
22 & $1.40 \pm 0.01$ & $32.14 \pm 5.40$ & $37.64 \pm 3.45$ & $30.28 \pm 4.28$ & $50.47 \pm 0.87$ \\
23 & $1.41 \pm 0.01$ & $24.20 \pm 4.80$ & $49.00 \pm 1.51$ & $26.80 \pm 5.53$ & $46.16 \pm 2.86$ \\
25 & $1.38 \pm 0.00$ & $14.00 \pm 1.00$ & $53.50 \pm 1.50$ & $32.50 \pm 2.50$ & $49.90 \pm 0.04$ \\
27 & $1.45 \pm 0.00$ & $33.00 \pm 2.00$ & $46.00 \pm 2.00$ & $21.00 \pm 0.00$ & $48.99 \pm 1.77$ \\
28 & $1.39 \pm 0.00$ & $27.84 \pm 1.17$ & $34.06 \pm 0.77$ & $38.20 \pm 1.10$ & $41.74 \pm 1.36$ \\
29 & $1.45 \pm 0.01$ & $38.43 \pm 3.96$ & $39.18 \pm 3.51$ & $22.43 \pm 3.48$ & $48.42 \pm 1.60$ \\
30 & $1.41 \pm 0.01$ & $35.66 \pm 1.20$ & $38.33 \pm 0.88$ & $26.00 \pm 2.00$ & $53.95 \pm 1.92$ \\
\hline CV \% & 3.25 & 38.02 & 30.24 & 47.64 & 19.57 \\
\hline BD & & & & \\
\hline
\end{tabular}

$\mathrm{BD}=$ bulk density, $\mathrm{TSA}=$ total soil aggregates

AEZ 4. Silt particles $(0.05-0.002 \mathrm{~mm})$ in the soil samples varied from $34.06-59.50 \%$, where the highest $(59.50 \%)$ was recorded for AEZ 4 and the lowest (34.06\%) for soils of AEZ 28. Clay particles $(<0.002 \mathrm{~mm})$ in the soil samples varied from $21-38.20 \%$, where the highest clay content $(38.20 \%)$ was recorded for AEZ 28 and the lowest clay content $(21 \%)$ was for AEZ 27. The Soils of AEZ 1, 3, 23, 29 and 30 were of loamy texture, those of AEZ 4, 19 and 27 were silt loam and those of AEZ 22 and 28 were clay loam. Silty clay texture was found in AEZ 13 and silty clay loam texture in AEZ 25. Soil textures are good in the AEZ studied, because these were neither heavy nor light. So, it could be concluded that soils of the selective AEZs were good for crop production.
Total soil aggregates (TSA) varied from 26.48 to $53.95 \%$, where the highest and lowest TSA were recorded in soils of AEZ 30 and 13, respectively. Aggregate stability in different AEZs followed the order AEZ 30>22> $25>27>29>23>19>1>28>3>4>13$, where the values were $53.95,50.47,49.90,48.99,48.42$, $46.16,43.85,42.54,41.74,41.47,38.44$ and $26.48 \%$, respectively. The low TSA in the AEZ is due to high Na content in the Ganges Tidal Floodplain soil. To increase and maintain aggregate stability of soils, regular application of different organic materials (manures, compost, crop resides etc.) to crop fields are recommended which can enhance SOC as well as aggregate stability of soils. Organic C content in soils is low in Bangladesh because of improper land management and use of high 
rates of inorganic fertilizers, especially the $\mathrm{N}$ fertilizer urea, which stimulates microbial decomposition of organic matter the resultant effect being low soil aggregates.

\section{Soils chemical properties}

Soil $\mathrm{pH}$, organic $\mathrm{C}(\mathrm{OC}), \mathrm{C}$ stock $(\mathrm{CS})$ and total $\mathrm{N}(\mathrm{TN})$ varied among different AEZs (Table 2). Soil $\mathrm{pH}$ value varied 4.96-7.65, which was strongly acidic to slightly alkaline. The highest $\mathrm{pH}$ (7.65) was recorded in soils of the AEZ 13 and the lowest (4.96) in AEZ 27. BARC (2018) ranked soils of AEZ 3, 22, $23,27,28$ and 29 as strongly acidic, soils of AEZ 1, 19, 25 and 30 as slightly acidic and soils of AEZ 4 and 13 as slightly alkaline.
Soil $\mathrm{pH}$ governs most physical, chemical and biological processes in soils which in turn may affect formation of soil aggregates. Among the soil organic matter decomposer microbial communities, bacteria and fungi are dominant and bacteria prefer a neutral soil reaction, while fungi like acidic soils for their functions (Rousk et al., 2009). Bacteria and fungi greatly influence soil aggregate formation. Six et al. (2002) reported several biological processes resulting in the formation of soil biological macro-aggregates which include the release of exudates from both bacteria and fungi which facilitate strong bonding among soil particles and help formation of aggregates. Also, fungal hyphae may encapsulate fine soil particles into aggregates.

Table 2. Soil pH, organic C, C stock and $\mathbf{N}$ contents in different AEZs of Bangladesh

\begin{tabular}{lcccc}
\hline \multirow{2}{*}{ AEZ No. } & \multicolumn{4}{c}{ Chemical characteristics of soils (mean \pm S.E.) } \\
\cline { 2 - 5 } & $\mathrm{pH}$ & OC $(\%)$ & CS (t/ha) & TN $(\%)$ \\
\hline 1 & $5.70 \pm 0.28$ & $0.93 \pm 0.11$ & $19.75 \pm 2.44$ & $0.07 \pm 0.02$ \\
3 & $5.44 \pm 0.24$ & $0.81 \pm 0.10$ & $17.25 \pm 2.13$ & $0.07 \pm 0.02$ \\
4 & $7.44 \pm 0.38$ & $1.22 \pm 0.04$ & $25.46 \pm 0.76$ & $0.11 \pm 0.00$ \\
13 & $7.65 \pm 0.14$ & $0.81 \pm 0.05$ & $16.73 \pm 1.04$ & $0.07 \pm 0.02$ \\
19 & $5.82 \pm 0.22$ & $1.29 \pm 0.45$ & $25.95 \pm 8.26$ & $0.11 \pm 0.11$ \\
22 & $5.18 \pm 0.17$ & $1.01 \pm 0.10$ & $21.27 \pm 2.04$ & $0.09 \pm 0.03$ \\
23 & $5.47 \pm 0.26$ & $0.92 \pm 0.18$ & $19.60 \pm 3.79$ & $0.08 \pm 0.03$ \\
25 & $6.29 \pm 0.38$ & $0.98 \pm 0.05$ & $20.48 \pm 1.13$ & $0.08 \pm 0.00$ \\
27 & $4.96 \pm 0.38$ & $0.88 \pm 0.06$ & $19.22 \pm 1.41$ & $0.08 \pm 0.00$ \\
28 & $5.33 \pm 0.04$ & $0.94 \pm 0.02$ & $19.54 \pm 0.43$ & $0.08 \pm 0.02$ \\
29 & $5.22 \pm 0.16$ & $1.04 \pm 0.10$ & $22.76 \pm 2.13$ & $0.09 \pm 0.03$ \\
30 & $6.15 \pm 0.32$ & $1.05 \pm 0.23$ & $22.31 \pm 4.86$ & $0.09 \pm 0.03$ \\
\hline CV \% & 8.44 & 43.67 & 39.35 & 40.81 \\
\hline
\end{tabular}

$\mathrm{OC}=$ organic carbon, $\mathrm{CS}=$ carbon stock, $\mathrm{TN}=$ total nitrogen 
Soil OC varied from $0.81-1.29 \%$ across AEZs (Table 2) studied. The highest OC was recorded for AEZ 19 and the lowest for AEZ 3 and 13. Soil OC content was found to be very low in all the AEZs. The lower OC content is the result of continuous intensive crop cultivation solely depending on inorganic fertilizers with little or no application of organic fertilizers (Rahman, 2013). Furthermore, high temperature and moisture in the tropical and subtropical countries like Bangladesh stimulate microbial decomposition of inherent and applied crop residues or organic fertilizers. Such conditions result in low $\mathrm{OC}$ as well as low $\mathrm{N}$ contents in soils. Organic $\mathrm{C}$ content in soil is one of the vital components that may largely regulate soil physical, chemical and biological properties and play a tremendous role in soil aggregate formation. Kumar et al. (2013) reported that plants and soil organic matter played a vital role in the formation of soil aggregates where the quantity of $\mathrm{OM}$ application and their quality especially $\mathrm{C}$ content govern the formation and stabilization of soil aggregates.

Roy et al. (2019) found that high organic C enhanced soil aggregate formation. Organic matter acts as a glue in binding soil particles together and makes soil aggregates stronger. Improvement in soil structure contributes to nutrient retention and as well as erosion control. As the OC content in soils of the selected AEZs of Bangladesh is low, the potential of aggregate formation is also low. Hence, regular application of organic materials whatever the sources is recommended to maintain soil health and productivity.

Four basic cations ( $\mathrm{Na}, \mathrm{K}, \mathrm{Ca}, \mathrm{Mg}$ ) found in the soils of different AEZs under study are presented in Table 3. The exchangeable $\mathrm{Na}^{+}, \mathrm{K}^{+}, \mathrm{Ca}^{+}$and $\mathrm{Mg}^{+}$contents in soils varied widely $\left(\mathrm{Na}^{+} 0.05-1.54, \mathrm{~K}^{+} 0.09-0.29, \mathrm{Ca}^{+}\right.$ $1.98-21.21$ and $\mathrm{Mg}^{+} 0.51-2.64 \mathrm{cmol} / \mathrm{kg}$ ). The highest exchangeable $\mathrm{Na}^{+}, \mathrm{K}^{+}, \mathrm{Ca}^{+}$and $\mathrm{Mg}^{+}$ contents were found at AEZ 13, while the lowest amount of exchangeable $\mathrm{Na}^{+}$and $\mathrm{K}^{+}$ were found in AEZ 1, and $\mathrm{Ca}^{+}$and $\mathrm{Mg}^{+}$in AEZ 30. The exchangeable $\mathrm{Na}^{+}$contents in all the AEZs were moderate, whereas $\mathrm{K}^{+}$contents were very low. Islam (2008) reported that most of the soils of Bangladesh (75\%) contained $\mathrm{K}$ below critical level and $17 \%$ below the optimum level. The $\mathrm{Ca}^{+}$contents were found to be optimum to high and $\mathrm{Mg}^{+}$were found to be at the optimum level in all the AEZs. Research findings revealed that monovalent cations like $\mathrm{Na}^{+}$and $\mathrm{K}^{+}$may have a dispersive effect in soils, while divalent cations $\mathrm{Ca}^{2+}$ and $\mathrm{Mg}^{2+}$ show flocculation effects (Rengasamy and Marchuk, 2011).

\section{Aggregate stability in different soil particle fractions}

It was observed that the stability of soil aggregates increased with the decrease soil particle size with some exception (Fig. 1). Higher amounts of aggregates were found in $0.25 \mathrm{~mm}$ sized soil samples. The trend of aggregate stability of different sized soil samples under different AEZs followed the order $0.25>0.50>1>2 \mathrm{~mm}$. Soil aggregates in $0.25 \mathrm{~mm}$ sized soil samples varied from 115 to $200 \mathrm{~g} / \mathrm{kg}$, with the lowest in AEZ 13 and the highest in AEZ 4. Aggregates stability in $2 \mathrm{~mm}$ sized soil sampled varied from 46 to $143 \mathrm{~g} / \mathrm{kg}$, with the lowest in AEZ 13 and the highest in AEZ 25. Roy et al. (2019) found that smaller sized soil particles contributed to a higher degree of aggregate stability. Soil 
S. Arofi, M. M. Rahman, H. K. Shiragi, M. A. Alam, M. M. Islam, and J. C. Biswas

Table 3. Basic cations in soils of different AEZs of Bangladesh

\begin{tabular}{lcccc}
\hline & \multicolumn{3}{c}{ Basic cations in soils (c-mol $/ \mathrm{kg})(\mathrm{Mean} \pm \mathrm{S} . \mathrm{E})}$. \\
\hline 1 & $\mathrm{Na}^{+}$ & $\mathrm{K}^{+}$ & $\mathrm{Ca}^{2+}$ & $\mathrm{Mg}^{2+}$ \\
\cline { 2 - 4 } 3 & $0.05 \pm 0.01$ & $0.09 \pm 0.00$ & $3.07 \pm 0.81$ & $1.34 \pm 0.06$ \\
4 & $0.09 \pm 0.01$ & $0.11 \pm 0.02$ & $2.91 \pm 0.30$ & $1.15 \pm 0.10$ \\
13 & $0.11 \pm 0.00$ & $0.13 \pm 0.01$ & $6.36 \pm 1.20$ & $1.55 \pm 0.10$ \\
19 & $1.54 \pm 0.16$ & $0.29 \pm 0.01$ & $21.21 \pm 1.60$ & $2.64 \pm 0.20$ \\
22 & $0.75 \pm 0.26$ & $0.11 \pm 0.01$ & $5.12 \pm 0.37$ & $1.48 \pm 0.37$ \\
23 & $0.21 \pm 0.02$ & $0.16 \pm 0.01$ & $3.74 \pm 0.57$ & $1.18 \pm 0.19$ \\
25 & $0.54 \pm 0.12$ & $0.14 \pm 0.01$ & $4.87 \pm 0.76$ & $1.43 \pm 0.35$ \\
27 & $0.20 \pm 0.01$ & $0.12 \pm 0.02$ & $3.05 \pm 0.62$ & $1.00 \pm 0.19$ \\
28 & $0.19 \pm 0.01$ & $0.10 \pm 0.02$ & $2.76 \pm 0.11$ & $1.90 \pm 0.30$ \\
29 & $0.29 \pm 0.02$ & $0.13 \pm 0.00$ & $6.50 \pm 0.51$ & $1.64 \pm 0.07$ \\
30 & $0.21 \pm 0.05$ & $0.18 \pm 0.04$ & $2.80 \pm 0.44$ & $0.91 \pm 0.14$ \\
\hline $\mathrm{CV} \%$ & $0.07 \pm 0.01$ & $0.22 \pm 0.03$ & $1.98 \pm 0.52$ & $0.51 \pm 0.07$ \\
\hline
\end{tabular}

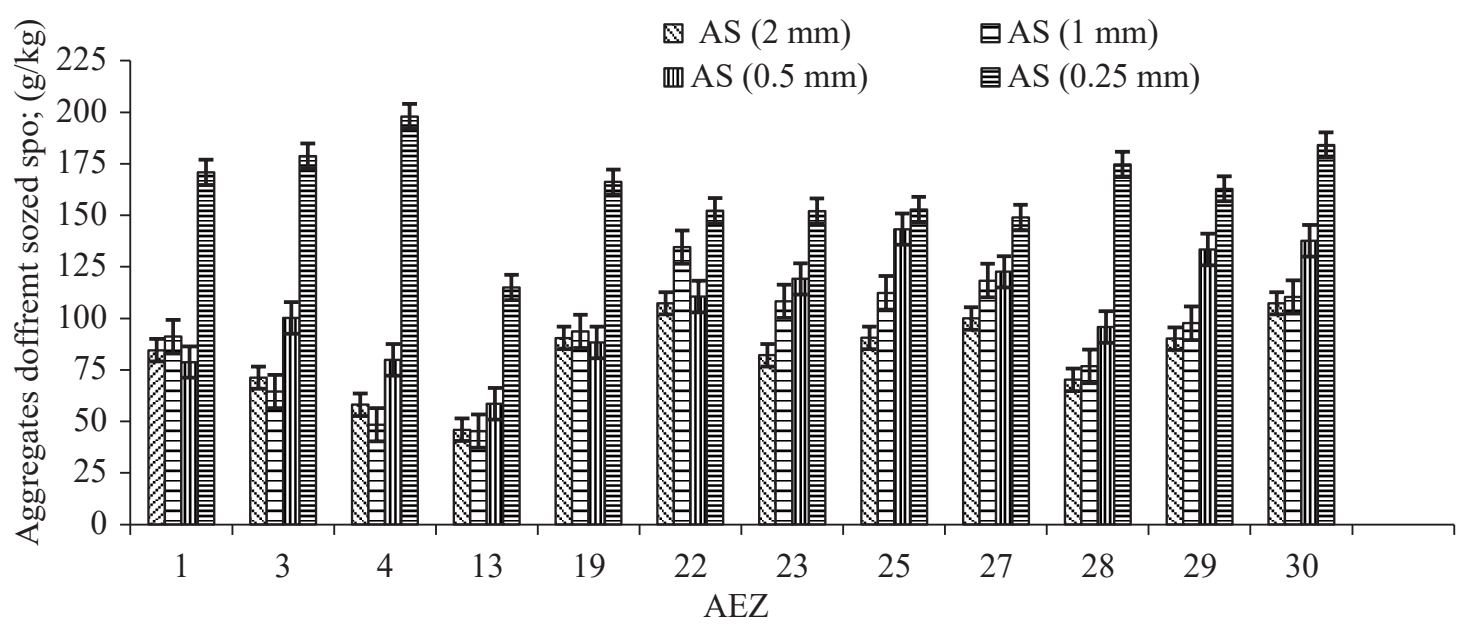

Fig. 1. Water stable soil aggregates of different soil particle size fractions in different AEZs of Bangladesh (AS = aggregate stability). 
and crop management practices may affect and breakdown larger aggregates, while the smaller aggregates may exist in high percentage (Simansky, 2013). Aggregate size distribution and its stability can change considerably because of tillage method (Singh et al., 2014; Beare et al., 1994). Lands usage and management (cropping systems) are important factors influencing soil aggregates size distribution and stability (Lebron et al., 2002).

Among the 12 AEZs in the present study, the lowest amount of water stable soil aggregates was found in AEZ 13 i.e. in the Ganges Tidal Floodplain. Because of higher concentration of $\mathrm{Na}^{+}$in the soils of AEZ 13, soil aggregates dispersed and hence the lower soil aggregate content.

\section{Effects of monovalent and divalent basic cations on soil aggregates stability}

The monovalent basic cations $\mathrm{Na}^{+}$and $\mathrm{K}^{+}$showed negative relation with soil aggregates (Fig. 2). Decreasing the amount of $\mathrm{Na}^{+}$in soil was found to be increasing soil aggregates. Similar results were also found in case of $\mathrm{K}^{+}$content and aggregate stability of soils. Since $\mathrm{Na}^{+}$and $\mathrm{K}^{+}$ disperse clay particles, they hinder aggregation

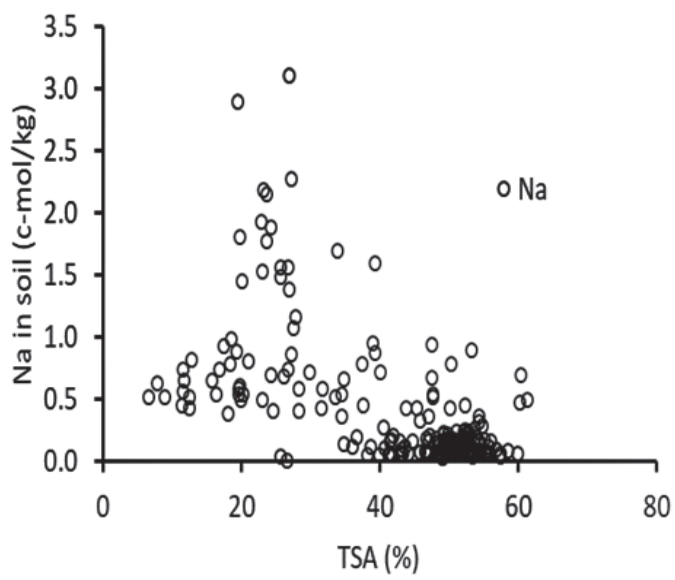

of soil and negatively affect soil structure. Sodium and $\mathrm{K}^{+}$can cause clay dispersion and swelling which result in the degradation of soil aggregates (Rengasamy et al., 2016).

The divalent basic cations $\mathrm{Ca}^{+}$and $\mathrm{Mg}^{+}$also showed negative relation with soil aggregates (Fig. 3). Data indicated that $\mathrm{Ca}^{2+}$ and $\mathrm{Mg}^{2+}$ increased soil aggregates. Correlation matrices of different ratios of basic cations like SAR, MCAR and CROSS with aggregates also showed negative relations (Table 4.4). Although, divalent cations $\mathrm{Ca}^{2+}$ and $\mathrm{Mg}^{2+}$ are known as flocculating agents (Rengasamy and Marchuk, 2011), they showed dispersion effect in the current study. Contradictions exist in case of $\mathrm{Ca}^{2+}$ and $\mathrm{Mg}^{2+}$ on their capability either as flocculating and / or dispersing agents in soil systems. Curtin et al. (1994) and Keren (1991) reported that $\mathrm{Mg}^{2+}$ enhances dispersion of soil aggregates in many cases; however, the efficacy of $\mathrm{Ca}^{+}$ as a flocculating agent is documented in many cases. The diameter of a hydrated $\mathrm{Ca}^{2+}$ ion is slightly less than that of $\mathrm{Mg}^{2+}$ ion and therefore, $\mathrm{Ca}^{2+}$ adsorbs more strongly on clay surface (Gardner, 2003). Furthermore, higher mobility and abundance of $\mathrm{Mg}^{2+}$ ion in

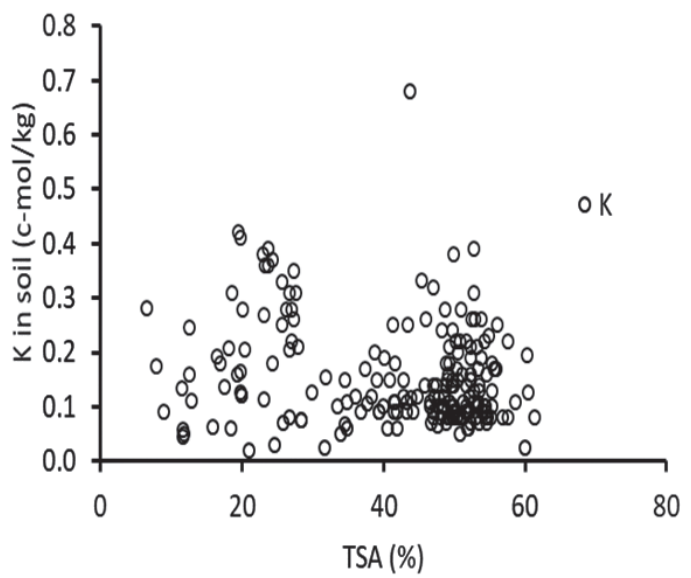

Fig. 2. Relationship between $\mathrm{Na}^{+}$and $\mathrm{K}^{+}$with total soil aggregates (TSA). 

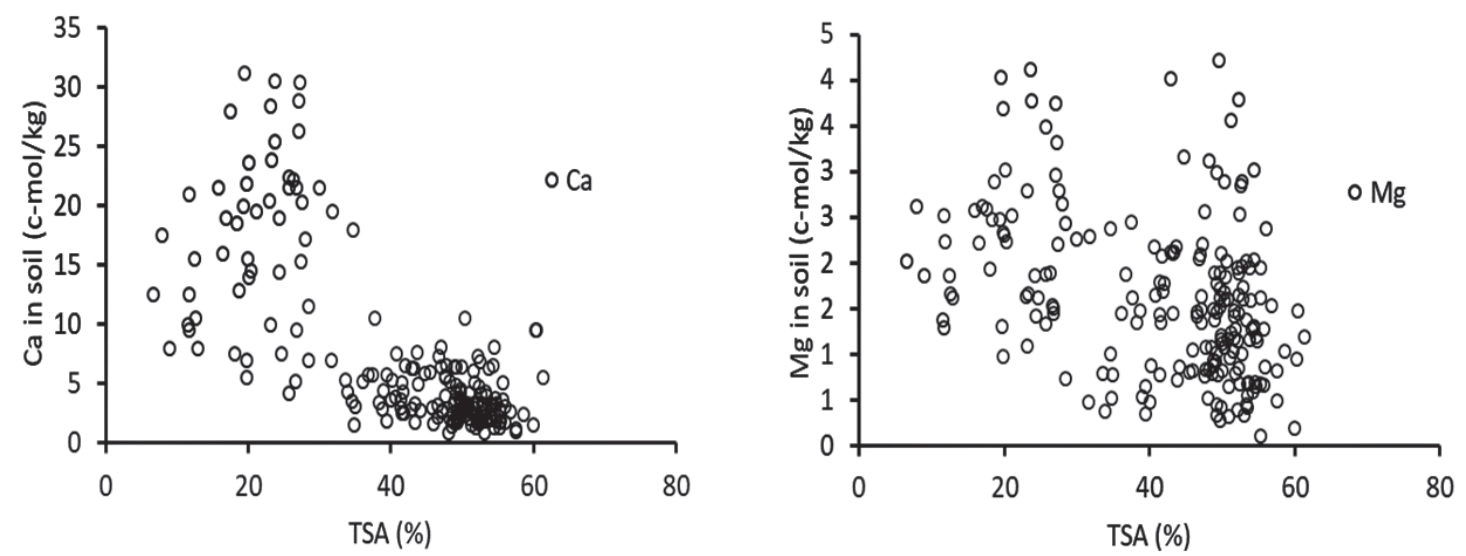

Fig. 3. Relationship between $\mathrm{Ca}^{2+}$ and $\mathrm{Mg}^{2+}$ with total soil aggregates (TSA).

soils attributes weaker formation of organomineral bonding and thus contributes to less aggregated soils (Gransee and Fuhrs, 2013).

\section{Conclusions}

Soil organic C content was found to have positive and monovalent basic cations have negative effects on aggregate stability of soil, while divalent basic cations played indistinct roles which need to be studied further. Aggregate stability and $\mathrm{C}$ stock in the 0.25 $\mathrm{mm}$ sized soil fraction were higher than those in larger sized soil fractions.

\section{Acknowledgements}

The study was funded by Research Management Wing (RMW) of Bangabandhu Sheikh Mujibur Rahman Agricultural University, Gazipur 1706, Bangladesh.

\section{References}

Alam, M. A., M. M. Rahman, J. C. Biswas, S. Akhter, M. Maniruzzaman, A. K. Choudhury, A. B. M. S Jahan, M. M. U. Miah, R. Sen, M. Z. U. Kamal, M. A. Mannan, M. H. K. Shiragi, W. Kabir and N. Kalra. 2019. Nitrogen transformation and carbon sequestration in wetland paddy field of Bangladesh. Paddy Water Environ. 17(4): 677-688.

BARC. 2018. Fertilizer Recommendation Guide. Bangladesh Agricultural Research Council, Farmgate, Dhaka 1215, Bangladesh.

Beare, M. H., P. F. Hendrix and D. C. Coleman. 1994. Water-stable aggregates and organic matter fractions in conventional-and notillage soils. Soil Sci. Soc. Am. J. 58(3): 777-786.

Castellanos-Navarrete, A., A. Chocobar, R. A. Cox, S. Fonteyne, B. Govaerts, N. Jespers and N. Verhulst. 2013. Soil aggregate stability by wet sieving: A practical guide for comparing crop management practices. International Maize and Wheat Improvement Center, Spain, 1-4.

Curtin, D., H. Steppuhn and F. Selles. 1994. Clay dispersion in relation to sodicity, electrolyte concentration, and mechanical effects. Soil Sci. Soc. Am. J. 58(3): 955-962.

Duiker, S. W., F. E. Rhoton, J. Torrent, N. E. Smeck and R. Lal. 2003. Iron (hydro) oxide crystallinity effects on soil aggregation. Soil Sci. Soc. Am. J. 67(2): 606-611.

Gardner, R. C. 2003. Genes for magnesium transport. Curr. Opin. Plant Biol. 6: 263267.

Gransee, A. and H. Fuhrs. 2013. Magnesium mobility in soils as a challenge for soil and plant analysis, magnesium fertilization and root uptake under adverse growth conditions. Plant Soil. 368: 5-21. 
Gee, G. W., and J. W. Baunder. 1986. Particle-size analysis 1. Methods of Soil Analysis: Part 1-Physical and mineralogical methods, 383-411. American Society of Agronomy, Agronomy Monographs 9(1), Madison, Wisconsin.

Gomez, K. A. and A. A. Gomez. 1984. Statistical Procedures for Agricultural Research. John Wiley \& Sons.

Islam, M. S. 2008. Soil fertility history, present status and future scenario in Bangladesh. Bangladesh J. Agric. Environ. 4: 129-151.

Jackson, M. L. 1973. Estimation of phosphorus content. Soil Chemical Analysis, Printer Hall, New Delhi (India).

Keren, R. 1991. Specific effect of magnesium on soil erosion and water infiltration. Soil Sci. Soc. Am. J. 55(3): 783-787.

Kumar, R., K. S. Rawat, J. Singh, A. Singh and A. Rai. 2013. Soil aggregation dynamics and carbon sequestration. J. Appl. Nat. Sci. 5(1): 250-267.

Lebron, I., D. L. Suarez and T. Yoshida. 2002. Gypsum effect on the aggregate size and geometry of three sodic soils under reclamation. Soil Sci. Soc. Am. J. 66(1): 92-98.

Paustian, K. A. O. J. H., O. Andren, H. H. Janzen, R. Lal, P. Smith, G. Tian and P. L. Woomer. 1997. Agricultural soils as a sink to mitigate $\mathrm{CO} 2$ emissions. Soil Use Manage. 13: 230-244.

Putte, A. van den, G., Goversa, J. K. DielsaGillijns and M. Demuzerea. 2010. Assessing the effect of soil tillage on crop growth: A meta-regression analysis on European crop yields under conservation agriculture. Eur. J. Agron. 33: 231-241.

Rahman, M. M. 2013. Nutrient-use and carbon sequestration efficiencies in soils from different organic wastes in rice and tomato cultivation. Commun. Soil Sci. Plant Anal. 44(9): 1457-1471.

Rahman, F., M. M. Rahman, G. K. M. Rahman, M. A., Saleque, A. S., Hossain and M. G. Miah. 2016. Effect of organic and inorganic fertilizers and rice straw on carbon sequestration and soil fertility under a ricerice cropping pattern. Carbon Manage. 7(1-2): 41-53.

Roy, S., M. M. Rahman, G. K. M. M. Rahman, M. G. Miah and M. Z. U. Kamal, 2019.
Structural stability under different organic fertilizers management in paddy soil. Ann. Bangladesh Agric. 23(1): 15-24.

Rengasamy, P. and A. Marchuk. 2011. Cation ratio of soil structural stability. Soil Res. 49: 280-285.

Rengasamy, P., E. Tavakkoli and G. K. McDonald. 2016. Exchangeable cations and clay dispersion: net dispersive charge, a new concept for dispersive soil. Eur. J. Soil Sci. 67(5): 659-665.

Rousk, J., P. C. Brookes and E. Baath. 2009. Contrasting soil $\mathrm{pH}$ effects on fungal and bacterial growth suggest functional redundancy in carbon mineralization. Appl. Environ. Microbiol. 75(6): 1589-1596.

Rowell, D. L. 1994. Chapter 14. The preparation of saturation extracts and the analysis of soil salinity and sodicity. Soil science: methods and applications. Ed. Rowell, DL, 277-302.

Schimel, J. P. and S. M. Schaeffer. 2012. Microbial control over carbon cycling in soil. Front. Microbiol. 3: 1-11.

Simansky, V. 2013. Soil organic matter in water-stable aggregates under different soil management practices in a productive vineyard. Arch. Agron. Soil Sci. 59(9): 1207-1214.

Singh, R. C., L. Sangeeta and C. D. Singh. 2014. Conservation tillage and manure effect on soil aggregation, yield and energy requirement for wheat (Triticum aestivum) in vertisols. Indian J. Agricul. Sci. 84(2): 267-271.

Six, J., E. T. Elliott and K. Paustian. 2000. Soil structure and soil organic matter II. A normalized stability index and the effect of mineralogy. Soil Sci. Soc. Am. J. 64(3): 1042-1049.

Six, J., R. T. Conant, E. A. Paul and K. Paustian. 2002. Stabilization mechanisms of soil organic matter: implications for C-saturation of soils. Plant Soil. 241(2): 155-176.

Thomas, G. W. 1982. Exchangeable cations. Methods of soil analysis. Part 2. Chemical and microbiological properties, (methodsofsoilan2), 159-165.

Walkley, A. and C. A. Black. 1934. An examination of the Degtjareff method for determining soil organic matter and a proposed modification of the chromic acid titration method. Soil Sci. 37(1): 29-38. 